\title{
RELIEF DEVELOPMENT OF THE BABIA GÓRA MASSIF, WESTERN CARPATHIAN MOUNTAINS
}

\author{
ADAM ŁAJCZAK \\ Institute of Geography, Pedagogical University, Cracow, Poland \\ Manuscript received: January 15, 2014 \\ Revised version: February 21, 2014
}

ŁajСZAк A., 2014. Relief development of the Babia Góra massif, Western Carpathian Mountains. Quaestiones Geographicae 33(1), Bogucki Wydawnictwo Naukowe, Poznań, pp. 89-106, 13 figs. DOI 10.2478/quageo-2014-0006, ISSN 0137-477X

\begin{abstract}
The paper discusses structural considerations relating to landform development on Mt. Babia Góra (1,725 $\mathrm{m}$ a.s.l.), the highest massif in the flysch section of the Western Carpathian Mountains. The Babia Góra massif consists of folded Palaeogene-age sediments, including resistant Magura sandstone and less resistant sub-Magura layers, with numerous tectonic faults. The area has inverse-type geomorphology. The monoclinal ridge of the massif itself consists of the resistant Magura sandstone dipping southwards. Since the Miocene, the development of the massif's relief has involved a number of processes, including: tectonic uplifting, removal of a thick layer of rocks, exposure of sub-Magura layers over a large area, the staged development of valleys dissecting the pediments surrounding the ever higher ridge, and slope retreat due to deep landsliding. Axes of linear terrain forms, escarpments of landslide scars and of headwater areas follow two main intersecting fracture lines present within the massif. Large quantities of colluvial material are transported away from the massif along these lines. The development of the land relief has led to the elongation of slopes as local elevation differences increased. Landsliding has developed in an uphill direction, which means that the youngest relief is observed on the highest sections of steep slopes. The development of the massif's northern slope, which has formed a high and precipitous cuesta, began to accelerate only after a nearly complete exposure of the sub-Magura layers at its foot. Following this exposure the profile of the massif's N-S cross-section has begun to become asymmetrical. With time, the degree of general remodelling of the massif has tended to decrease. As a result, the geomorphological contrast between the northern and southern sides of the massif has become well established. The description of the probable development of the Babia Gorra relief is based on the author's fieldwork, an analysis of geological maps and aerial photos, and on literature.
\end{abstract}

KEY wORDS: structural control of relief development, landslide morphology, cuesta slope, dip slope, Carpathian Mountains

Address of the corresponding author: Adam Łajczak, Institute of Geography, Pedagogical University, Podchorażych 2, 30-084 Kraków, Poland, e-mail: alajczak@o2.pl

\section{Introduction}

Studies on the long-term development of mountain relief include examination of both the altitude at which remains of planation surfaces of various ages are found on ridges and the scale of valley deepening in lower sections of the mountains during intervals between such planation stages. An example of this approach is large-scale research in the Polish Carpathian Mountains during the 1960s and 1970s (Starkel 1969, 1972, Baumgart-Kotarba 1974). Recently however, the view that remains of old planation 
surfaces can be found in the Carpathian Mountains has been put in doubt (Zuchiewicz 2011). Nevertheless, geomorphologists have continued to study clean-cut examples of large planation surfaces, especially those found on the foreland of high articulated slopes (cuesta slopes) and in areas of plate geology, in both cases involving sandstone rocks (Migoń 2008, Demek et al. 2011, Kasprzak 2013, Łajczak 2013). The deepening valleys progressively dissect these areas leading to elongation of slopes and to an increase in mountain relief energy. In mountains built of softer rocks, such as flysch, this type of morphology development leads to increased landsliding. Landslide relief often dominates this landscape. Slope retreat leads to narrowing of mountain ridges, particularly on cuesta slopes. While landslides offer a rewarding subject of geomorphological research (Bober 1984, Hutchinson 1988, 1995, Brunsden 1993, Cendrero, Dramis 1996, Cruden, Varnes 1996, Dikau et al. 1996, Margielewski 2006, Alexandrowicz, Margielewski 2010, Pánek et al. 2010) published research offers no data concerning the rate of retreat in case of slopes with landslides in areas where valley deepening rates have been estimated. The combination of those two parameters would help reconstruct probable development of mountain ridges in areas of staged uplift and dissection. A good understanding of local geology would provide a basis for the assessment of the role of structural geology in relief development of in such areas.

Mt. Babia Góra (1,725 $\mathrm{m}$ a.s.l.) is the highest massif the flysch section of the Western Carpathian Mountains, with well recognized geology and geomorphology (Książkiewicz 1983, Łajczak 2013). It offers a promising subject for research concerning structural impacts on relief development during the Neogene and the Quaternary period. Indeed development of its relief was closely linked with uplifting of the massif, staged dissection, planation of its foot and with slope retreat. The research published so far failed to address sufficiently the structural framework for the development of the massif relief which is unique in the flysch section of the Western Carpathians.

\section{Study area}

\section{Geology and general outline of Babia Góra relief}

Babia Góra Mountain is the highest massif in the western flysch Carpathians, reaching the altitude of 1,725 $\mathrm{m}$ a.s.l., located at the Polish-Slovak border (Fig. 1A). It consists of a monoclinic ridge with an asymmetric cross section. The orientation of the $10 \mathrm{~km}$ long ridge is generally west to east. The local height differences reach $1,100 \mathrm{~m}$ on its northern side and $900 \mathrm{~m}$ on the southern side (Fig. 1B). The Babia Góra massif and its surroundings form a part of the predominantly flysch Western Carpathian Mountains formed in the Alpine orogeny. The massif is a folded structure within the Magura nappe. The massif consists mainly of Palaeogenic sandstone and shale rocks uplifted in an orogeny during the Miocene. Highly resistant Magura sandstone forms the top section of the massif, above $900-1,000 \mathrm{~m}$ a.s.l. in a syncline the axis of which coincides with the foot of the southern slope. The northern flank of the syncline consists of sandstone formations dipping southwards. The southern flank is toppled, reduced and largely eroded (Fig. 1C). For this reason the Babia Gora massif should be regarded a homoclinal ridge, with axial zone running along outcrops of sandstone formations that build the syncline's northern flank. This section of the ridge consists of the most resistant layers of Magura sandstone with silica cement. The northern concave slope of the ridge is a cuesta with an average gradient of $40^{\circ}$ in the upper part and locally up to $70^{\circ}$, where 5-80 m high rockwalls occur. The southern dip slope shows a convex-concave profile and is slightly steeper, at $20^{\circ}$ to $30^{\circ}$, than the dip angle of the underlying sandstone layers. A western section of the southern slope, which will be hereafter referred to as the western slope, is dissected by the massif's longest and deepest valleys. The profiles of this slope fall somewhat in between those of the southern and northern slopes (Fig. 1B). The Magura sandstones are interbedded with shale and less-resistant sandstone formations. Wherever the latter formations outcrop on the northern side the slopes tend to be less steep and in some places feature flat areas. Less 
A

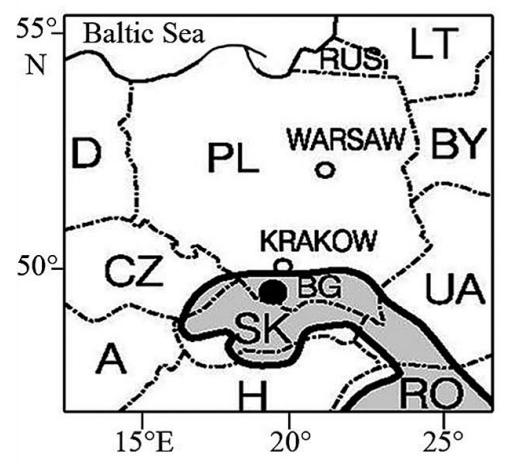

B

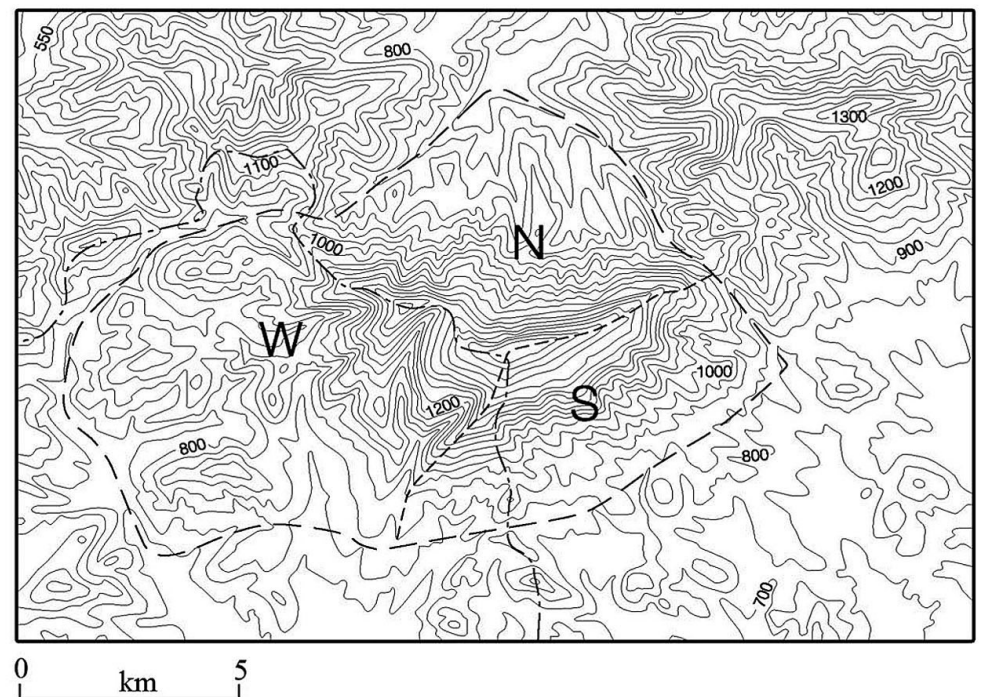

C

$\mathrm{N}$

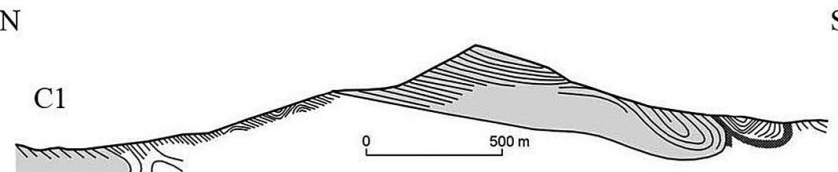

mingme
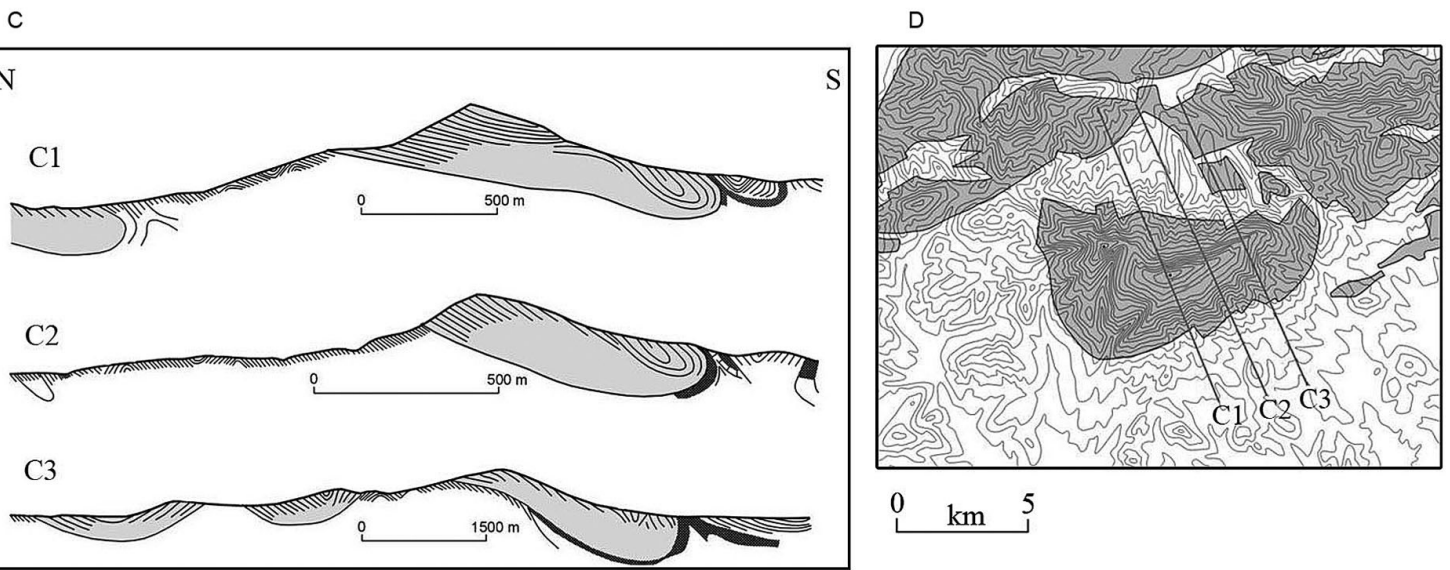

$0 \mathrm{~km} 5$

$\mathrm{E}$
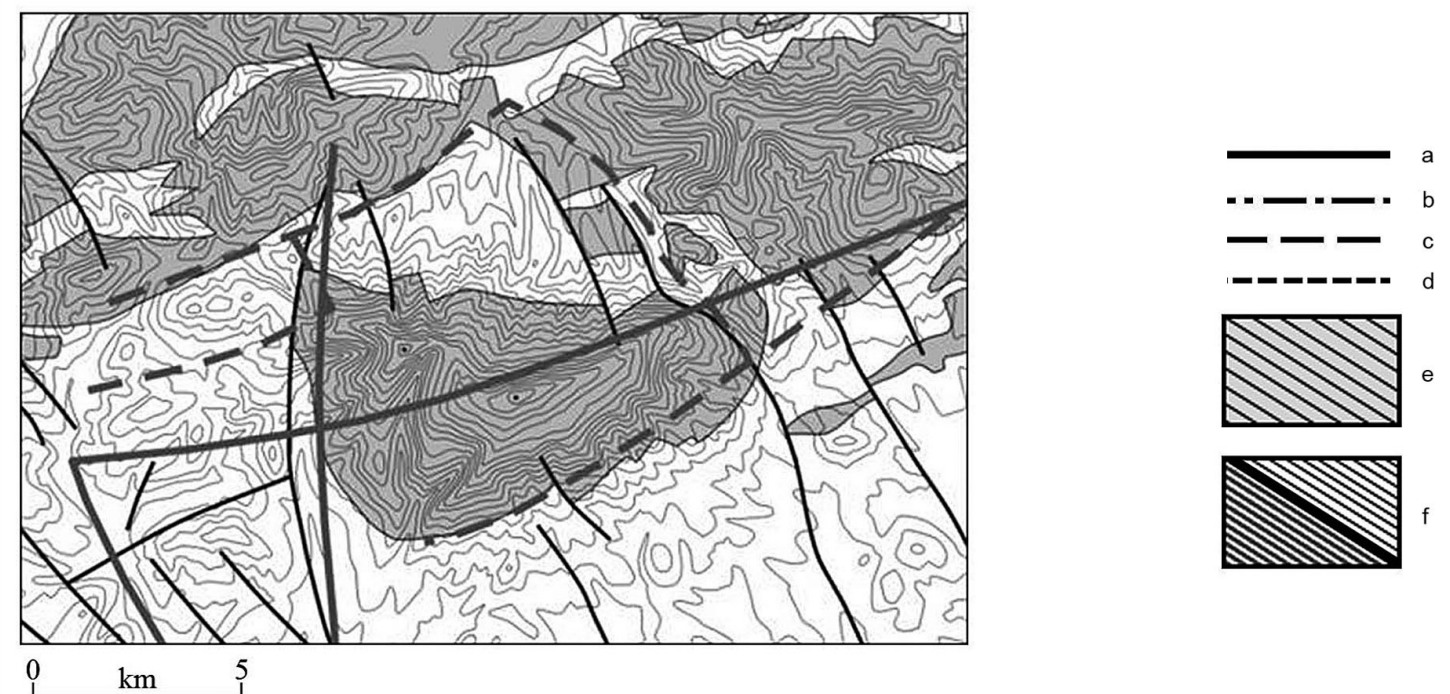

Fig. 1. Study area. A - location of the Babia Góra massif, B - hypsometry, C - selected geological profiles (according to Książkiewicz 1983), D - location of the profiles, E - extent of Magura sandstone outcrops (grey background) and sub-Magura layers (white background), faultlines (thin continuous lines), photolineaments (broken lines) and topolineaments (thick broken lines). $\mathrm{a}$ - limit of the Carpathian Mountains, $\mathrm{b}$ - state border, $\mathrm{c}$ - limit of the massif, $\mathrm{d}$ - limit of the northern $(\mathrm{N})$, western (W) and southern (S) slopes of the massif, e - Magura sandstones, f - sub-Magura layers. BG - Babia Góra massif 
resistant sub-Magura layers (sandstone, shale) are found folded below the Magura sandstone (Fig. 1C, D). Their outcrops are found at the foot and in the lower sections of the massif, the largest are found on the western and southern sides. Valleys and deep mountain passes have formed on outcrops of these sub-Magura layers.

The Babia Góra massif displays a mixture of geomorphological features typical of medium-altitude and high mountains (Starkel 1972, Baumgart-Kotarba 1974, Łajczak 2012, 2013). Due to high reflief energy and relatively low-resistant bedrock material the development of slope relief is primarily driven by structurally influenced landsliding processes (Fig. 2). For this reason most of the slope surfaces are occupied by landslide scars and colluvial covers of various dimensions composed of block-type rubble. Landslide scars located high on the northern side were glacially remodelled. On the top summit section and on its slopes periglacial landforms and sediments (including cryoplanation terraces, rock-block covers, chutes in solid rock and torrential cones) (Eajczak 2012, 2013) occur. Due to the abundance of water within the massif, fluvial processes are highly active. Their presence is manifested by valley deepening, especially at the foot of the northern slope where small waterfalls occur (Starkel, Łajczak 2008, Łajczak 2004, 2012).

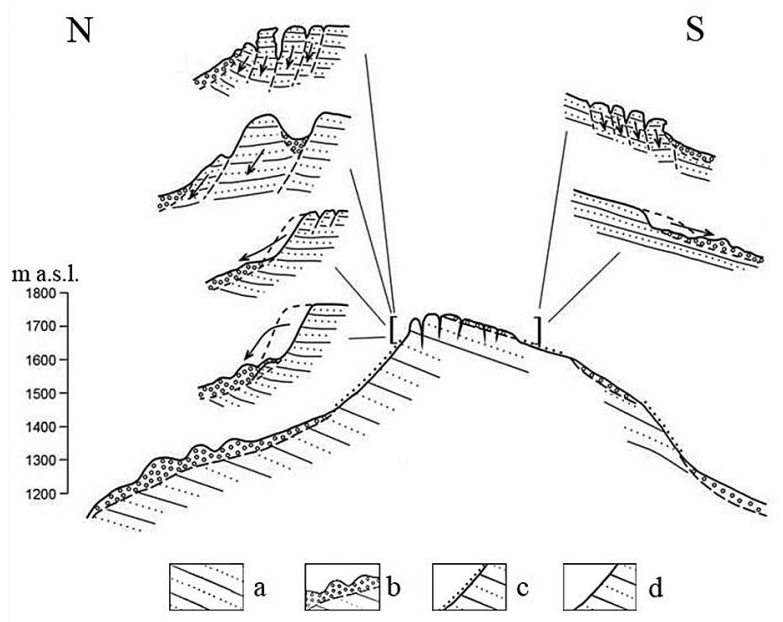

Fig. 2. Schematic cross-section of the top section of the Babia Góra massif highlighting landslide forms and deposits. $\mathrm{a}$ - Magura sandstones, $\mathrm{b}$ - thick rubble and block-type colluvial covers, $\mathrm{c}$ - thin waste-mantle, $\mathrm{d}$ - rocky cliffs

\section{Products of relief development}

A number of landforms or their remains were left by succeeding stages of geomorphological development that began in the Miocene: (1) sections of planation surfaces of various ages, (2) valleys of various pattern and depth, (3) headwater areas of various sizes and altitude, (4) slopes of various profiles, lengths and gradients, (5) landslide scars of various sizes and various altitudes vis-àvis landforms (1)-(3), (6) the main ridge - its axis is linked to the vertical reach of the landforms (3) and (5). The development of these landforms was influenced by tectonic movements lifting the massif, fragmentation of its pediments, deepening and broadening of valleys, the retreat of headwater areas, the retreat of slopes mainly occurring by means of large-scale landslides, and by the lowering of the top summit section. The scale of relief development varies around the massif and can be visually ascertained to be the greatest on the northern slope and the smallest on the southern slope. These differences in the geomorphological development of the Babia Góra massif, primarily along a north-south axis, are caused by tectonic features and the greater rate of erosion on the wetter northern slope. An analysis of the landforms mentioned above allows a reconstruction of the massif's relief development from the Neogene until present. These landform changes occurred at time of a climate change, as it shifted from warm in the Miocene and Pliocene to cooler in the Quaternary and to cold during subsequent continental and mountain glaciation stages. This type of task is based on a good understanding of the area's geology and geomorphology (Książkiewicz 1983, Łajczak 2012, 2013).

\section{Previous research on the long-term geomorphological development of the massif}

The existing literature is limited to studies on specific aspects of the geomorphological development of the Babia Góra massif, such as landslide, glacial and periglacial relief. Since the 1950, research has increasingly focused on the role of structural landsliding in relief control, especially 
on the northern slope (Starkel 1972, Alexandrowicz 1978, Ziętara 1988, 2003, 2004, Łajczak 1998). So far, no study tracing the development of the entire massif back to its emergence from the Miocene sea has been published. Among the most important studies available is the seminal article by Alexandrowicz (1978), which discusses the role of structural features in development of landslides on the northern slope of Babia Góra massif and in retreat of that slope - as huge landslide scars developed ever higher, noting their elevation, volume and age (beginning from the Miocene). This publication inspired the author of this paper to study structural conditions for development of relief in entire massif. Early conclusions from this research are covered by the author's latest publications (Łajczak 2012, 2013), where he flags certain structural-geomorphological questions and presents the preliminary results of research on the long-term development of relief in the Babia Góra massif. Other landforms, such as valleys, headwater areas and ridges (especially the main ridge), were addressed only to a limited extent. More attention was given to analysis of asymmetrical slope profiles while investigating landslides and the remains of glacial relief linked to the geological structure and the climatic asymmetry of the main ridge (Eajczak 1998, 2013).

A reconstruction of the relief in this area requires critical approach to the identification of landforms marking the altitudes of planation surfaces. The need for a very careful approach to geomorphological analysis of the Carpathian Mountains has been advocated for many years (e.g. Starkel 1969, 1972, 1986, 1992, Baumgart-Kotarba 1974). Four mountain planation periods were determined in the Polish Carpathian Mountains: Upper Miocene, Lower Pliocene, Upper Pliocene and Lower Quaternary Periods; this was linked to the altitude ranges where the remains of the landforms analysed were found: a broad range mainly above $400 \mathrm{~m}, 250-400 \mathrm{~m}, 150-200$ $\mathrm{m}$ and below $100 \mathrm{~m}$ (Starkel 1969, 1972). An uplift of the rockmass following each phase of tectonic stabilisation leads to dissection of previously planated areas by watercourses and to formation of convex landforms and, gradually, mountain ridges in these places. The remains of planation periods include hill or mountain ridges built from resistant sandstones, with smooth long-pro- files. The oldest and highest level, known as the summit level, has long been regarded as dubious as its purported remains are found within a broad range of altitudes. This however, could be explained by subsequent tectonic deformations. In recent years, the view that planation was advanced in the Carpathian Mountains during these periods and that remains of the ancient planation surfaces could have been preserved, has come under close scrutiny and even outright questioning (see: Zuchiewicz 2011).

Traces of planation surfaces (apart from the oldest one), which are clearly visible in the Babia Góra massif and its surroundings, have been regarded an indicator of past changes in the extent of pediments at the foot of the main ridge and of increasing height differences on this ridge (Łajczak 2013).

The objective of this paper is to explain structural influence of relief development in the Babia Góra massif and its vicinity during the Neogene and the Quaternary Periods. It focuses specifically on trends in the development of the valleys and slopes as a consequence of incremental dissection of pediments and increased activity of landslides as local elevation differences increased. The paper examines differences in the development of relief between the northern, western and southern slopes of the massif.

\section{Methods}

The study involves analysis of local landform morphometry using topographic maps at a scale of 1:10 000. Geomorphological mapping of the area was also taken into account using a base map of the same scale. The author had conducted his own field studies in the area for the previous 15 years. The morphometry analysis also included the use of recent aerial photos. These analyses yielded the extent and size (length, width, depth/altitude, slope) of the following landforms: main ridge and its shoulders, valleys, headwater areas, landslide forms (trenches, scars, rock-walls, tongues, etc.). Numerous slope cross-section measurements were made at the locations of landslides and ridge cross-sections, including the marking of sections regarded as remains of planation surfaces. Azimuths of 
major linear forms were determined. These included the axes of valleys and ridges and relief articulations along the boundaries between valley bottoms and slopes and between the summit surface and adjoining slopes. Where the azimuth of a linear landform varied, each section had its azimuth taken separately. The extent of outcrops of various rock complexes and fault lines were outlined using geological maps (Książkiewicz 1983, Geological Atlas 1988-1989, Alexandrowicz 2004). The fieldwork also included determination of the slope of rock cliffs as well as sections of slopes covered with waste mantle of varying depths. The latter was measured on natural outcrops. The slope and outline of rock layers across the whole massif were determined using geological maps and additionally using field measurement. The fieldwork also included preparing schematic diagrams of structural axes (alignment of joint fractures, escarpments and landslide fissures). The results of these measurements at every site were compatible with the directions of fault lines and courses of rock layers.

\section{Results}

\section{Structural control}

Local height differences in the Babia Góra massif and its vicinity, slope gradients, azimuths of linear landforms, shapes of landslide scars and headwater areas all display spatially determined differences. Some of them vary greatly across the vertical profile of the area. This would suggest that geological structure exerts a strong influence the massif relief. In existing literature some of the features of the massif relief, such as great altitude and asymmetrical cross-profile, are explained by uplift greater than in the vicinity of the massif, the high resistance of the Magura sandstone found in the upper section of the ridge and its monoclinal pattern, as well as by greater rate of structural landsliding on the northern slope. The Magura sandstone is known as a "ridge-forming sandstone". On the other hand, less steep or flat sections of slopes are found on the less-resistant sandstone or on shale. In addition sub-Magura layers, the least resistant in the area, form the lowest sections of the massif and its foot.
Author's current research has identified a number of structural determinants of Babia Góra massif relief, which have been overlooked so far. The key determinant seems to be the direction of fracturing in the underlying rocks, which differs between the Magura sandstone (found in the main ridge) and the sub-Magura layers (both on the northern slope and at the foot of the northern and southern slopes). Two directions of fracturing dominate in these formations: NW-SE - linked to the faults and perpendicular to that - linked to the syncline and anticline axes (which are parallel to the course of the rock layers). The latter axis features local variations: in the Magura sandstone of the topmost section it is WSW-ENE, in the sub-Magura layers of the northern side it runs SW-NE, and in the same layers of the southern
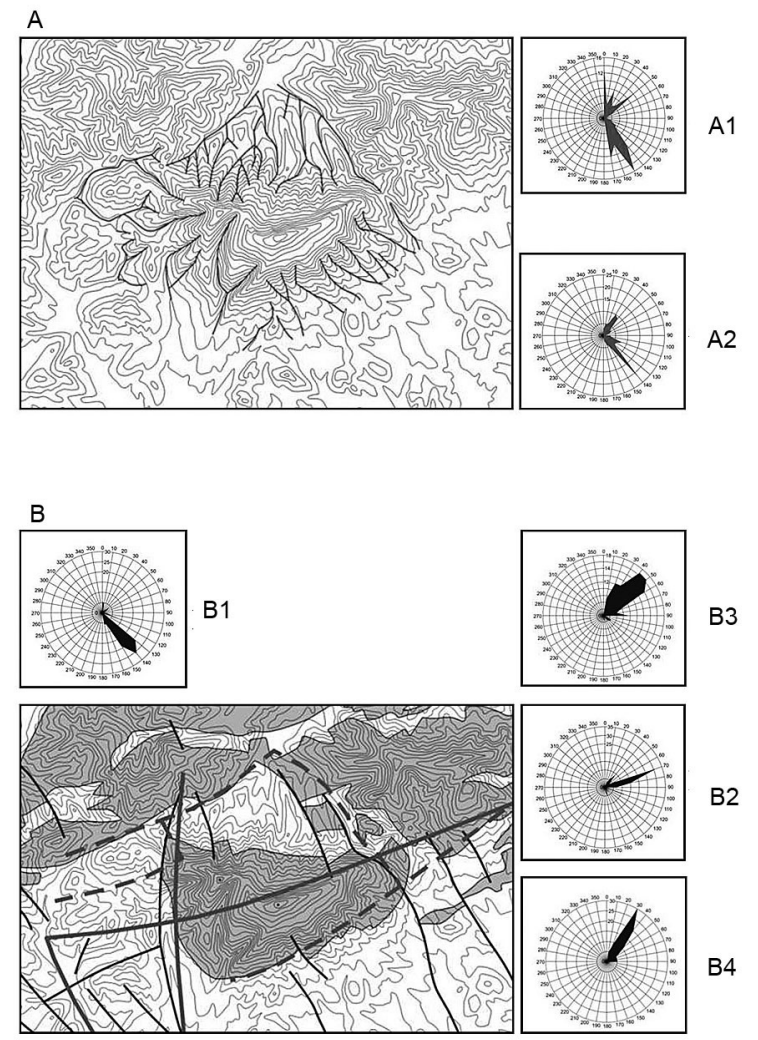

Fig. 3. Diagrams of valley axes and joint lines in the Babia Góra massif. A - valley pattern, B - lithology, faultlines, photolineaments and topolineaments (key as on Fig. 1E). Valley sector diagrams: A1 - northern slope, A2 - southern and western slopes. Sector diagrams: B1 - faultlines, B2 joint lines concurrent with the direction of Magura sandstone layers of the main ridge, B3 - in sub-Magura layers on the northern slope and the base, B4 - in the sub-Magura layers on the southern and western slopes and the base 
side it veers more towards N-S. Two main directions of fracture in the Magura sandstones of the Babia Góra massif define the lines of large rock masses movement, which in effect determine the valley and ridge pattern, including the main ridge (Figs 3 and 4). The axes of valleys on the southern and western slopes of the massif are strictly linked to the NW-SE and SW-NE axes, while on the steeper northern slope they are additionally linked to the N-S axis, which is also the main slope axis. The shoulders on the southern and western slopes of the massif follow the dominant NW-SE and SSW-NNE axes, but also secondary N-S and W-E axes. Side-ridges on the northern slope follow the same axes as on the southern slope, except W-E. Unlike the straight-line shoulders the main ridge follows a winding zigzagging course along two axes, NW-SE and WSW-ENE, which
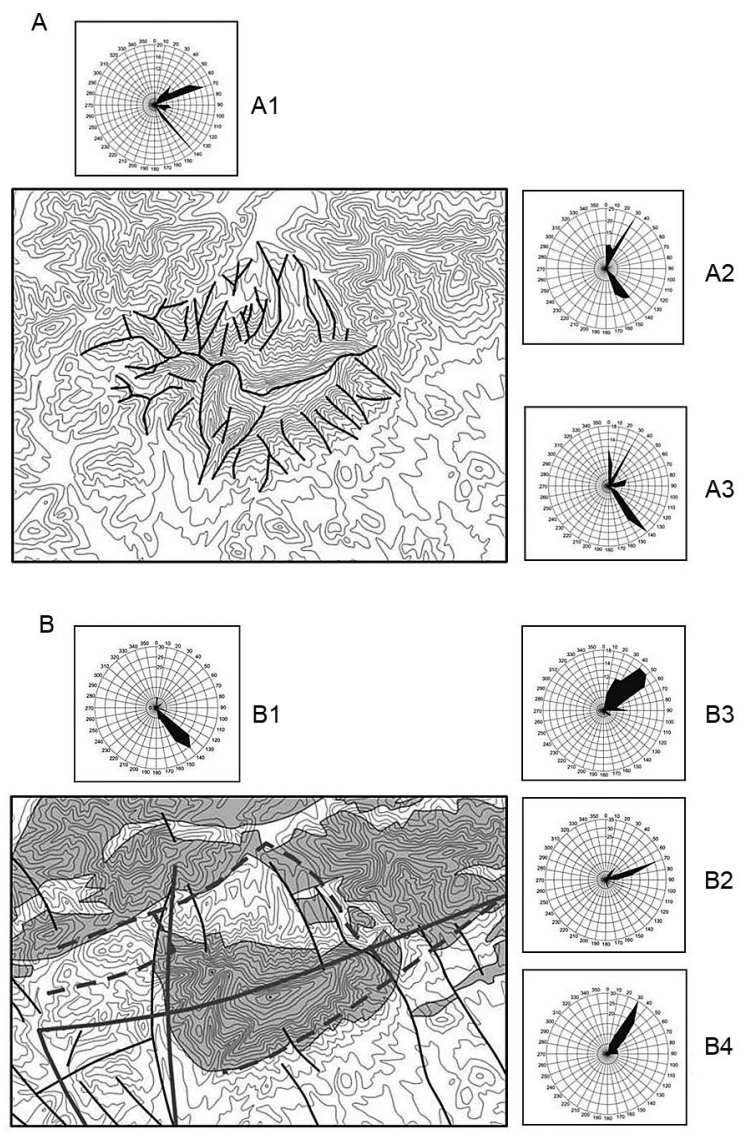

Fig. 4. Diagrams of ridge directions in the Babia Góra massif vs. joint lines. A - ridge pattern, B - lithology, faultlines, photolineaments and topolineaments (key as on Fig. 1E). Diagrams of ridge lines: A1 - main ridge, A2 - branching ridges in northern part, $\mathrm{A} 3$ - branching ridges in southern and western part. Key to B1-B4 as for Fig. 3 are strictly linked to the fracturing of Magura sandstone and a secondary $\mathrm{W}-\mathrm{E}$ axis.

Axes nearly identical to those of the main ridge are followed by other linear landforms in the Magura sandstone section, i.e. the edge of summit section and the slopes, convex articulations on slopes, the foot of steep (and especially precipitous) slope sections and concave articulations at the slope foot at valley bottoms. Mountain passes are found along these same lines on sub-Magura sandstone. It seems interesting that the same pattern is also found in the western section of the massif and its vicinity where only the sub-Magura layers outcrop (Fig. 5). The same conclusions can be drawn with regard to the slopes of "young" landslide scars and headwater areas which form clearly trapezoidal patterns and occur at least $100 \mathrm{~m}$ above the junction between the Magura and sub-Magura layers. The slopes of those landforms that are found at the point of contact between the two formations follow similar axes to those of the sub-Magura fracturing.

\section{Structural controls reflected in selected landforms}

The central, highest section of the northern slope of the main ridge forms a cliff of more than $400 \mathrm{~m}$ known as the huge rock slump of Babia Góra (Rehman 1895, Alexandrowicz 1978, 2004). The ridge also slopes down steeply on the southern side, but not quite as precipitously and only in its middle part (see: Figs 2 and 5). The northern slope of the massif has a concave section, while the southern slope is convex-concave. The steepness of these slope sections, greatest in the whole massif, is a result of the relationship between the slope of terrain and the slope of the resistant Magura sandstone layers. The heads of the rock-layers outcrop on both sides of the ridge which increases both the slope gradient and its rate of retreat. The smaller vertical extent of the outcrop on the southern slope than on the northern one causes reduction in slope length and rate of retreat on the southern side. Elsewhere within the main ridge slopes take a different form due to lower altitude and deeper fragmentation by valleys. This particular aspect of Babia Góra structural morphology has so far been overlooked. 


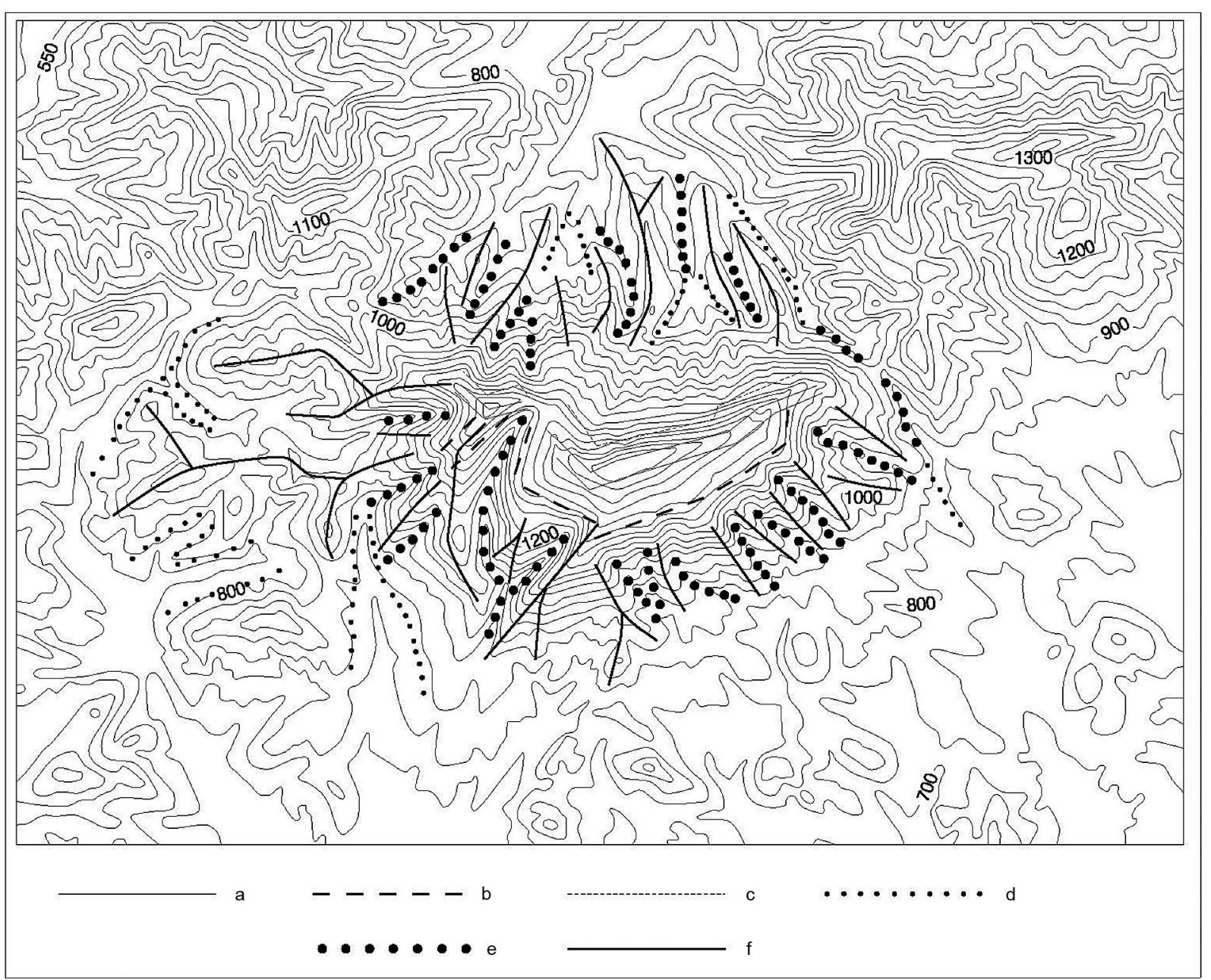

Fig. 5. Schematic diagram of the most legible linear landforms of the Babia Góra massif. a - edge of the main ridge top surface, $\mathrm{b}$ - axes of convex slope articulations beneath, $c$ - axes of concave slope articulations beneath precipitous sections, $\mathrm{d}$ - axes of concave slope articulations in the bottoms of flat-bottomed valleys at the foot of slopes, e - axes of narrow valleys, $\mathrm{f}$ - axes of side ridges

Valleys follow majority of the tectonic faults documented in the area. The remaining valleys run either in parallel or at right angles to these fault lines (see: Figs 4 and 5), possibly suggesting a denser network of fault lines, as tentatively suggested by geologists studying this area. For this reason a denser network of faults could explain a concentric pattern of valley network on the northern side, where the valleys cut down as much as $150 \mathrm{~m}$ deep into the softer sub-Magura layers. On the southern side of the massif valleys cut into the same rock formations, run along parallel faults with a tendency to be very short and do not exceed $100 \mathrm{~m}$ in depth. On the western side of the massif valleys follow densest fault line network (documented or presumed?) and some of them cross each other. This is the reason for the grid-pattern of the valley network, which is unique not just around Babia Góra, but also in the entire flysch-dominated Western Carpathian Mountains in Poland (grid valley patterns are common in the Eastern Carpathian Mountains). The valleys in this part of the Babia Gora massif are longest and deepest at up to $300 \mathrm{~m}$, and include both subsequent and gap reaches.

The pattern of the shoulder ridges reflects valleys pattern. On the northern slope of the massif all upper ends of the ridges fit in the narrow band of altitudes $800-900 \mathrm{~m}$ a.s.l. The ridges can be as long as $5 \mathrm{~km}$, mostly showing long stretches of smooth gradient in their long-sections, regarded as the remains of the foothill planation surface. Similarly smooth long-profiles of lower ridges and hills were regarded as remains of the lower-most valley planation surface. On the southern slope of the massif the shoulder 
ridges reach only 2 kilometres in length and run parallel to each other. Their top sections begin at $1100-1200 \mathrm{~m}$ a.s.l. and the ridges tend to be very steep with just one section regarded as a trace of the middle-mountain planation surface. Because of this profile the shoulders have been nicknamed "buttresses" or "escarpments" among local population. Shoulder ridges of the western section follow a grid pattern. The longest of them reach 7 kilometres and have the highest top ends beginning at $1400 \mathrm{~m}$ a.s.l. Their long-sections are uneven with culminations topping the adjacent mountain passes by $100 \mathrm{~m}$. Smooth sections of these ridges or their shoulders are regarded as relics of three planation surfaces, i.e. middle-mountain, foothill and valley.

\subsection{Stages of slope retreat due to landsliding}

Remains of four planation surfaces were identified, three of which elevated above the adjacent valley bottoms by the same altitude difference as those planation surfaces found by other researchers elsewhere in the Polish Carpathian Mountains (Fig. 6). The fourth and the highest planation surface is represented by smooth ridge sections, that are found at widely ranging altitudes from the Babia Góra itself to lower adjacent peaks. These sections consist of the resistant Magura sandstone (see: Fig. 1D and 6A, C). The varying altitudes can be explained by different degree of upthrust occurring along tectonic faultlines dividing the area. On the other hand, similar elevations above valley bottoms of the other planation surfaces can be explained by lower tectonic activity at the time of their development. The main ridge of the massif is surrounded by the planation surfaces. This suggests that its base, formed during the Neogene and Quaternary periods as a series of large pediments, underwent three phases of dissection by valleys. Each subsequent stage led to relative height difference enlargement, slopes elongation and eventually to an increase in the relief energy. The latter resulted in massive landslides with enormous niches, valleys deepening and at a more local scale, to the evolution of headwater areas. The extent of large landslide niches can be recognized by studying slope profile articulations that typically alternate between concave and convex landforms. The varied elevation of these niches points to their equally varied age. This aspect of geomorphological development of the Babia Góra's northern slope was highlighted by Alexandrowicz (1978).

One likely scenario emerging from this study on landforms evolution on the Babia Góra massif, involving upthrusting, valley deepening and slope retreat, is as follows. The local flysch formations had already been subject to extensive erosion before their emergence from the Miocene Sea. At that stage, the Magura sandstones were still buried and the erosion processes operated on the overlaying formations. Their eventual complete removal exposed the Magura sandstones - their erosion in dry conditions led to formation of the oldest planation surfaces in the Upper Miocene. Subsequently these have been significantly distorted as a result of tectonic movements. During the Lower Pliocene, continued erosion lowered the base of the initial Babia Góra massif by at least $250 \mathrm{~m}$. Considering the effects of varied rates of uplifting movements that occurred within the area, local relative altitude differences could have already exceeded $500 \mathrm{~m}$. At that stage local relief development became inverted, as anticlinal sub-Magura layers were exposed enabling formation of river valleys, while narrowing ridges developed on synclinal or monoclinal locations. A considerable depletion, complete in places, of the thick Magura sandstones on the northern foreland of the massif produced a cuesta-type slope. In the following long planation period, dated to the Lower Pliocene, rivers began to cut through the pediments surrounding the Babia Góra massif again and by the end of the Pliocene, average valley depth reached $200 \mathrm{~m}$. During that time the Magura sandstone at the base of the massif was almost completely eroded on its northern side, on the western side the erosion was complete. At that time the slopes of the main ridge retreated considerably and the current river network was established as well. The line of the northern slope, already a well-formed cuesta, was straight and its relative difference in altitude was close to $900 \mathrm{~m}$. Its upper end was approximately at the current contact point of the Magura and sub-Magura layers. The southern slope had seen much less retreat while the 
A

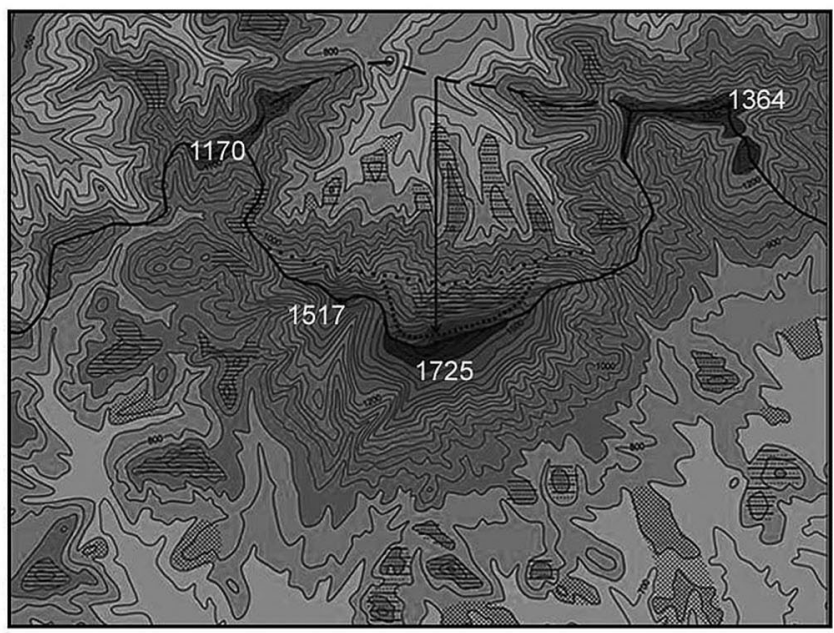

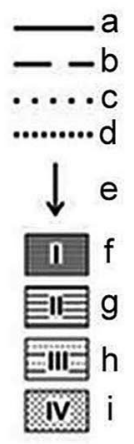

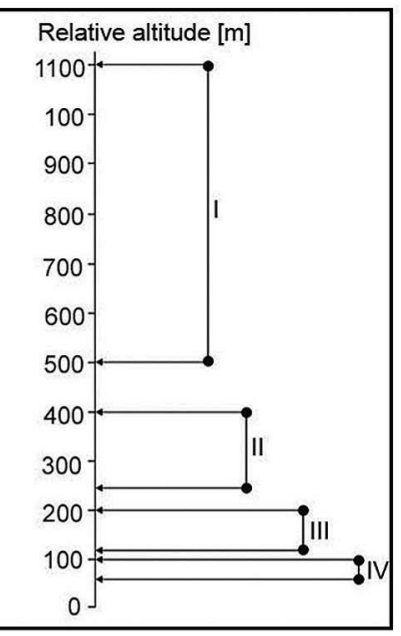

$\mathrm{C}$

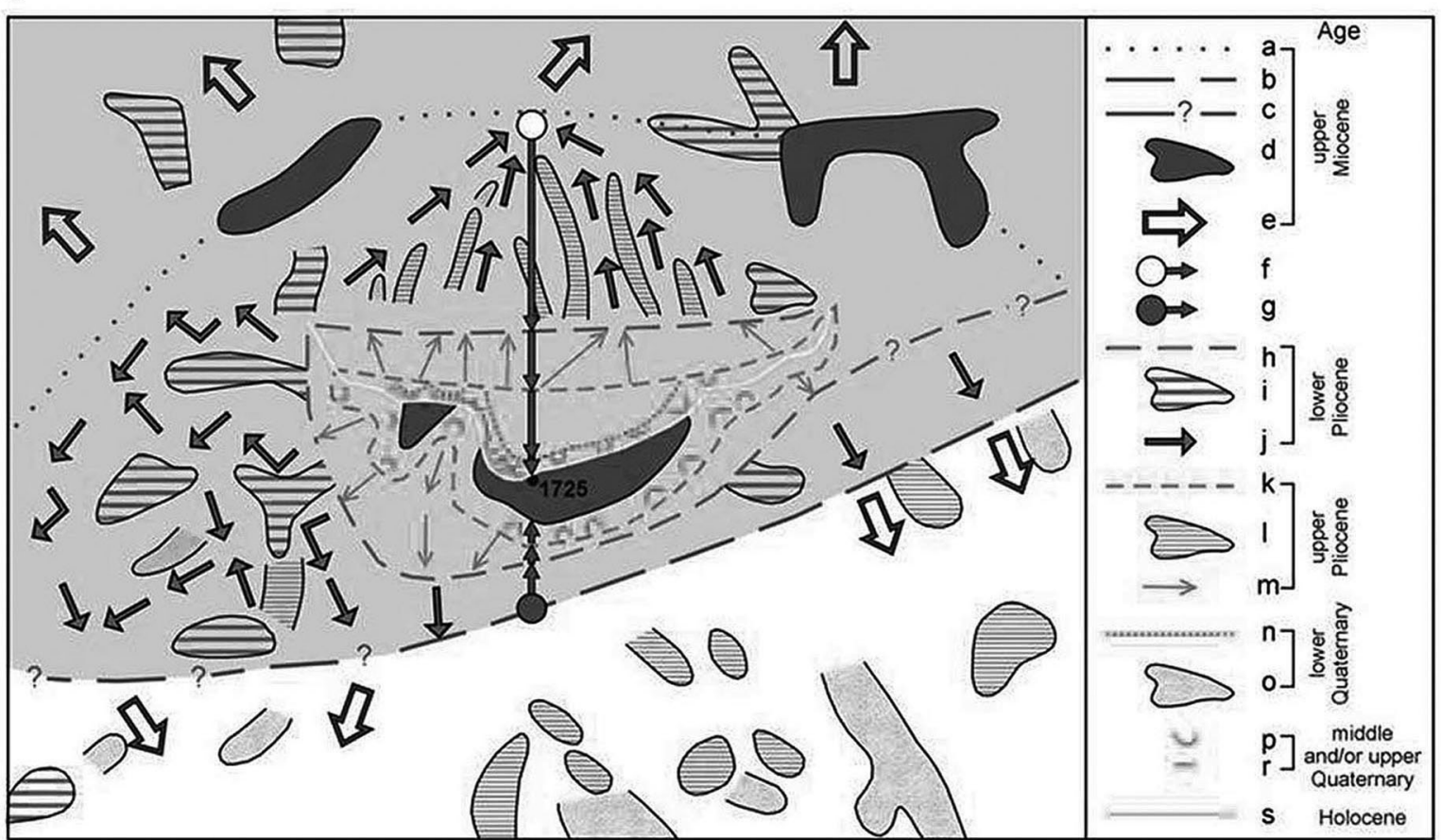

Fig. 6. Geomorphological sketch of the Babia Góra massif and its vicinity. A - location of four planation surfaces vs. area hypsometry, B - extents of relative altitudes of planation surfaces vs. valley bottoms, C - evolution of valley network and stages in slope retreat during the Neogene and Quaternary. Key to A: a - current main ridge axis within the massif and its vicinity, $\mathrm{b}$ - probable initial main ridge axis in an early stage of formation of the massif $\mathrm{c}$ - extent of large landslide niche covering the entire northern slope and developed during the Pliocene before formation of the foothill planation surface, $\mathrm{d}$ - extent of landslide niche on the northern slope formed at the turn of the Pliocene and Quaternary before the formation of the latest and lowest planation surface, e - extent of retreat of northern slope. Planation surfaces: $f$ - summit surface (I), $g$ mid-mountain surface (II), $\mathrm{h}$ - foothill surface (III), i - valley surface (IV). Key to C: a - initial course of main ridge near the massif, $\mathrm{b}$ - current southern extent of Magura sandstone outcrops near the massif, $\mathrm{c}$ - probable southern extent of Magura sandstone outcrops near the massif, $d$ - relics of the summit planation surface, $\mathrm{e}$ - earliest drainage directions, $\mathrm{f}$ - probable initial northern extent of massif, $g$ - probable initial southern extent of the massif, $\mathrm{h}$ - probable base of steep slopes of the massif before the establishment of the mid-mountain planation surface, $\mathrm{i}$ - relics of the mid-mountain planation surface, $\mathrm{j}$ - drainage directions on massif during Pliocene, $\mathrm{k}$ - probable base of steep slopes of the massif before the establishment of foothill planation surface, 1 - relics of the foothill planation surface, $\mathrm{m}$ - upper valley reaches established or deepened at the turn of the Pliocene and Quaternary, $\mathrm{n}$ - extent of large landslide niche on the northern slope developed at the turn of the Pliocene and Quaternary before the formation of the latest and lowest planation surface, o - relics of the valley planation surface, $\mathrm{p}$ - highest located Quaternary landslide niches (including some transformed in glacial and nival conditions), $\mathrm{r}$ highest located deep ridge trenches, $\mathrm{s}$ - contemporary main ridge axis. Black arrows pointing from (f) and (g) to the summit illustrate the scale of retreat of the northern and southern slopes 
western slope had already been dissected by deep valleys. After the third planation period in the Upper Pliocene, subsequent dissection of pediment reached the approximate depth of only $100 \mathrm{~m}$ without changing the course of valleys. The altitude difference on the northern slope reached about $1,000 \mathrm{~m}$ and on the southern slope $800 \mathrm{~m}$. This stage of slope dissection was likely associated with further rapid slope retreat, especially on the northern side. A large landslide niche of that age, with dimensions of $1 \times 3 \mathrm{~km}$ and a depth of $500 \mathrm{~m}$, can be found on the northern slope. It was formed as a result of long-lasting slope retreat caused by extensive landslide activity that also considerably affected the main ridgeline. The latest planation process that followed in the Lower Quaternary affected the massif surroundings. The subsequent valley deepening did not exceed $100 \mathrm{~m}$ and the scale of the slope retreat was similarly modest, with an exception of the steepest sections where numerous deep landslide niches developed, especially on the northern side. Being the youngest these landforms have steep rocky slopes.

The massif slopes were dissected along lines linked with the main axes of joint in the underlying rock formations. Valleys formed along these lines, as well as colluvium transport routes that lead into the valleys. An example of the landforms mentioned is a very large niche formed on the northern slope in the late Pliocene/early Quaternary period, its bottom "hangs" 400 $\mathrm{m}$ above the current valley bottom (Fig. 6A,C). Cross-sections of that niche are shown in Fig. 7. Niche walls are built of the most resistant Magura sandstone layers, while less resistant formations are found in its bottom. The shape of the niche is markedly trapezoidal and its edges are strictly linked to the main joint lines in the Magura sandstones. On the slope beneath, between the niche and the point of contact between the Magura and sub-Magura layers, geomorphological effects of gravitational tectonics, i.e. multiple trenches, are visible, their lines matching the main joint in the Magura sandstones. Colluvial material near these trenches tends to be rather thin. Also small rocky cliffs are visible there. The thickness of the waste-mantles increases both up the slope and, to a lesser extent, down the slope.
Scarps of the youngest, Quaternary landslide niches also match the general axes of joint in the Magura sandstones. Some of these niches are headwater areas. All of these landforms are found along the entire vertical profile of the massif slopes. On the northern slope niches occur within two altitude zones separated by a broad belt covered with a thick layer of wasterock colluvia (Fig. 8). The shape of the niches changes from semi-circular in the lower slopes to trapezoidal higher up thus indicating that the latter are younger. Scarps of the youngest niches are often rocky and the niches are covered with a thin waste-mantle, primarily of block type boulders. The older niches tend to be less steep, with thicker waste-rock and loamy covers.

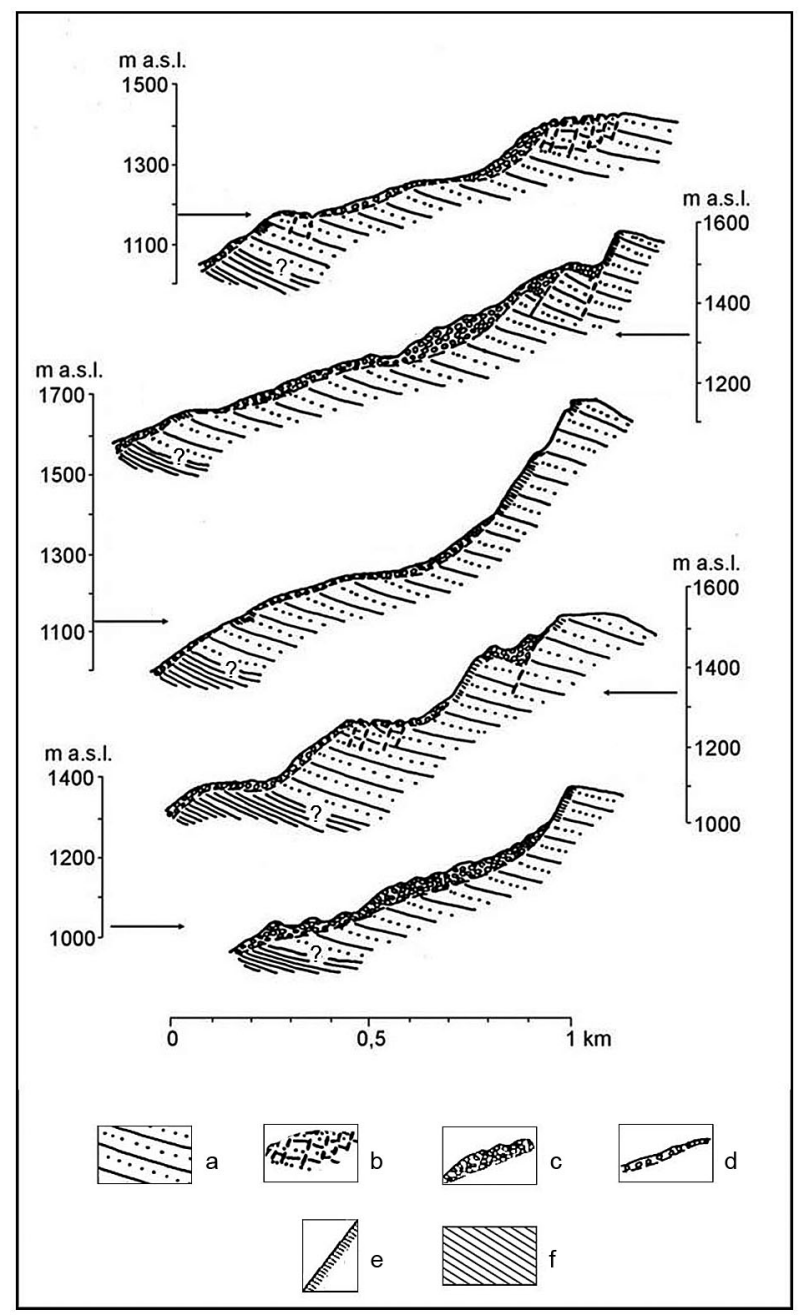

Fig. 7. Cross-sections of the large niche on the northern slope developed at the turn of the Pliocene and Quaternary. Location of the niche is shown on Fig. 6A,C. a - Magura sandstones, $\mathrm{b}$ - deep cracking of the sandstone, $\mathrm{c}$ - thick colluvial cover, $\mathrm{d}$ - thin colluvial cover, e - rocky cliffs, f - sub-Magura layers 


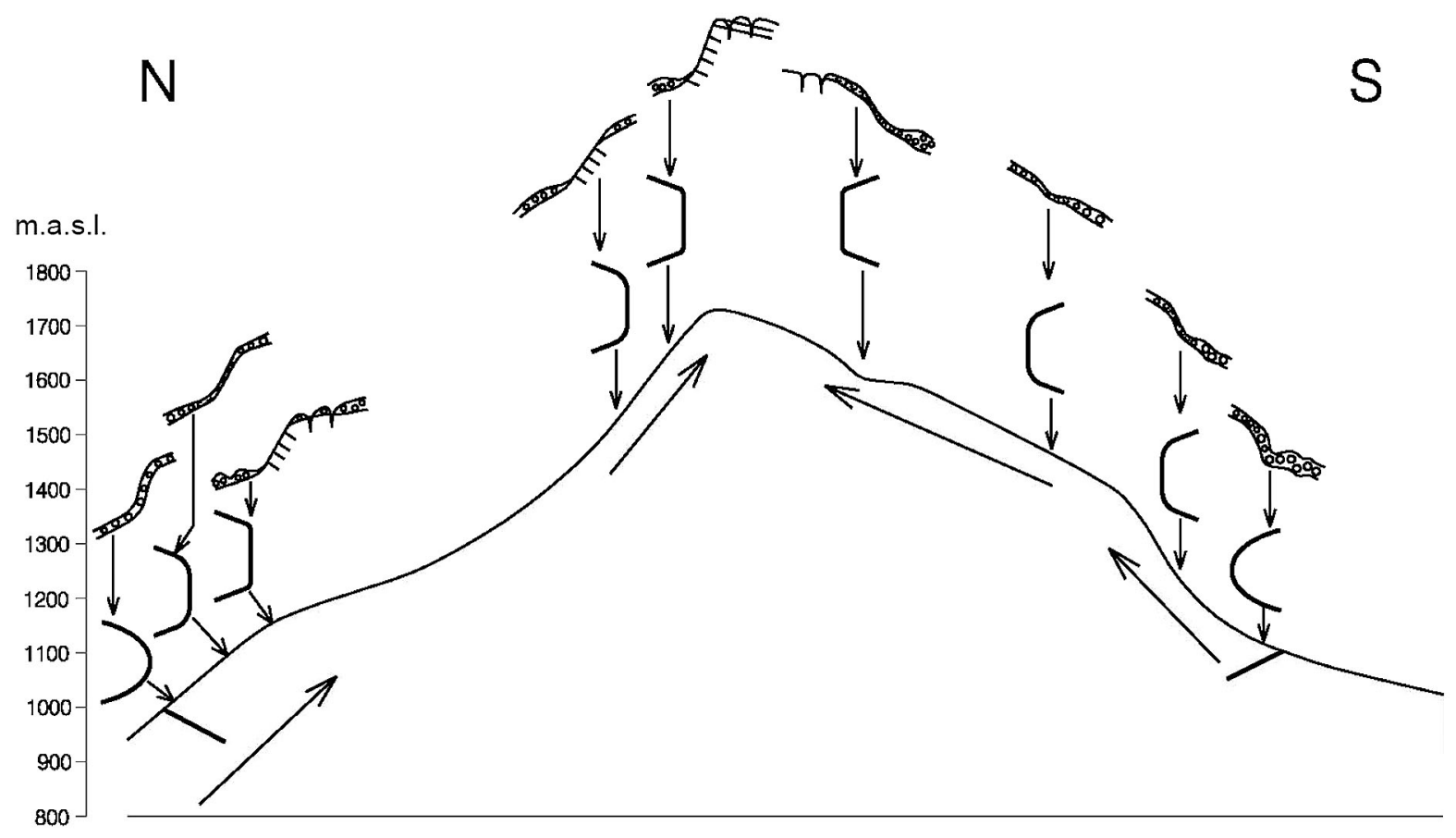

Fig. 8. A range of shapes of young and small landslide niches thickly lined with waste mantle on the southern and northern slopes of Babia Góra. Long arrows indicate directions of slope development

\section{Causes of the rectangular valley pattern in the western part of the massif}

The valley system of the western part of the massif follows a rectangular pattern and their extent is aligned with either of the two main joint lines in the Magura sandstone (see: Figs 3 and $6 \mathrm{C}$ ). The system must have developed in the Magura layers, taking the form that was suited to this specific geology and then survived the complete erosion of these formations. Indeed, over time the rivers cut deeper into the sub-Magura layers, but the valley pattern remained unaltered.

\section{Location of headwater areas vs. landslide relief}

Large headwater areas are found around the highest part of the Babia Góra massif at different altitude and within different distance from the top part of the main ridge (Fig. 9). The altitude of the headwater areas depends both on the stage of progress of the landsliding relief in a given slope section and on the thickness of waste/block mantle on the slope. The most elevated are headwater areas in western sections of the northern slope with their upper edges only 100-200 metres beneath the main ridge. The development of headwater areas at this location is a result of a longer valley evolution history in this part of the northern slope than in the other parts. Headwater areas of the western, highly dissected slope tend to reach similar altitudes. In both cases evolution of headwater areas is facilitated by limited thickness of the colluvial covers. In contrast, the zone of headwater areas on the southern, highly dissected slope is located much lower at $200-400 \mathrm{~m}$ below the ridge top surface. Headwater areas in the middle and eastern parts of the northern slope are located lower. They occur below the enormous landslide niche, much of which is lined with thick rubble and block-type colluvial cover up to several tens of metres thick. Because this part of the massif has not been dissected by even shallow valleys, the zone of headwater areas is only found $200-600 \mathrm{~m}$ below the ridge flat. 


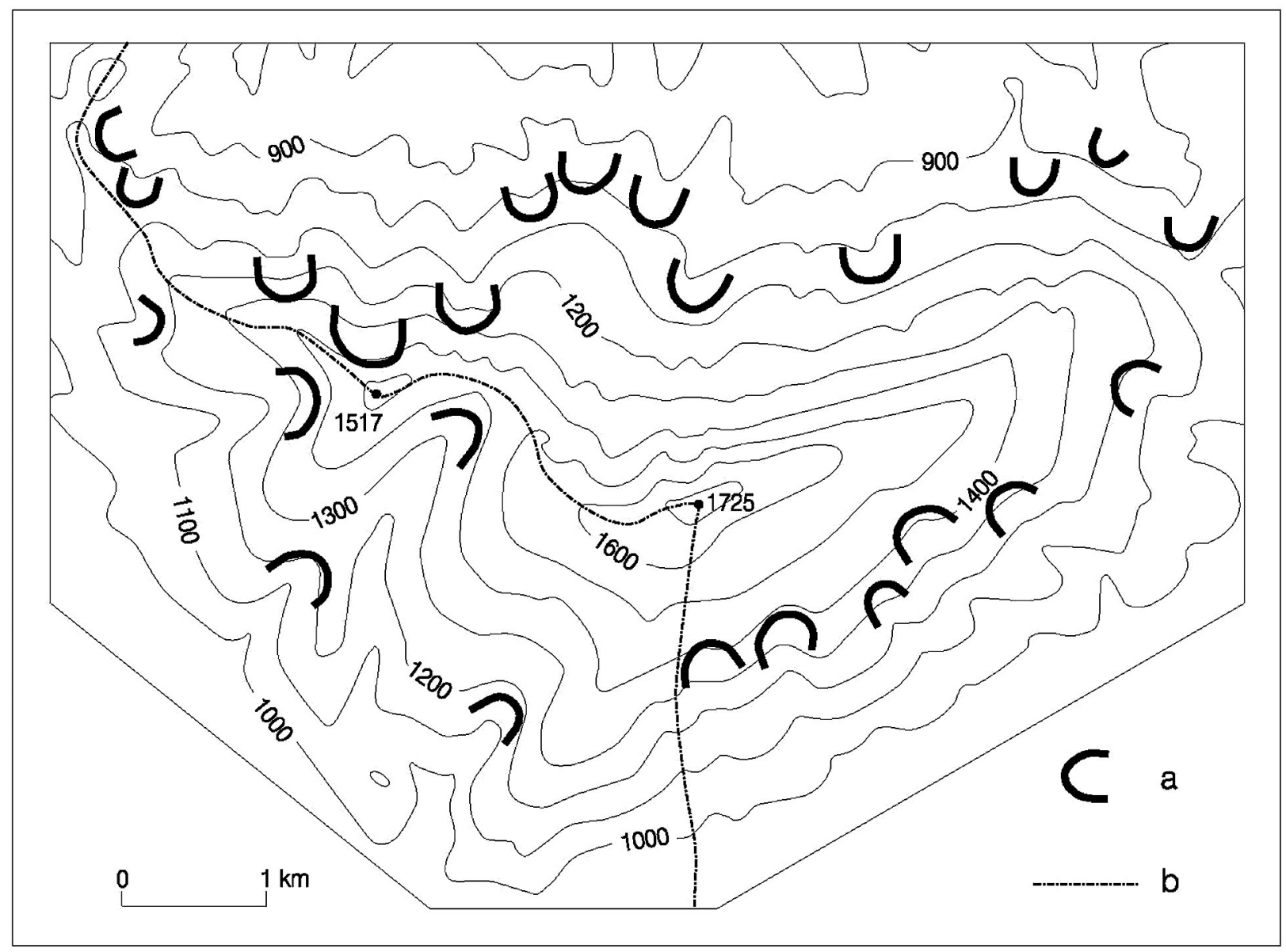

Fig. 9. Distribution of the largest headwater areas in the Babia Góra massif. a - headwater areas, b - Polish/Slovak state border

\section{Main ridge pattern}

The zigzagging course of the Babia Góra main ridge (Figs 4A, 5, 6A and 9) is imposed by different stages of development of the landslide relief and by the altitude of headwater areas. Evolution of the large landslide niche on the northern slope pushed the central ridge section axis about one kilometre to the south. Headwater areas of central and partly eastern section of the northern slope as well as the southern slope are located low on the slopes and thus have no impact on the main ridge pattern, which mainly follows a straight line. On the other hand, in the massif western section, vis-à-vis the ridgeline, high and asymmetrical location of headwater areas produced a winding ridge. A local summit developed in this part of the ridge flanked by mountain passes. The ridge pattern along this section, with segments corresponding to cracks in the Magura sandstones, may be regarded stable, in contrast to the eastern section, where different altitudes of headwater areas influence course of the ridgeline - especially on southern slopes.

\section{Final remarks on relief evolution in the Babia Góra massif}

Four areas with different scales of landform change were identified within the Babia Góra massif. Major geomorphological features of this area are covered in the key to Fig. 10. The highest rate of slope retreat is found in the northern part of the massif, while deepest valleys have formed in its western part. Erosion on the largest scale took place on northern and western slopes; in the latter case valleys cut into the sub-Magura layers. At the base of the western slope and over most of the northern base Magura sandstone formations were eroded completely. Evolution of long valleys 
A

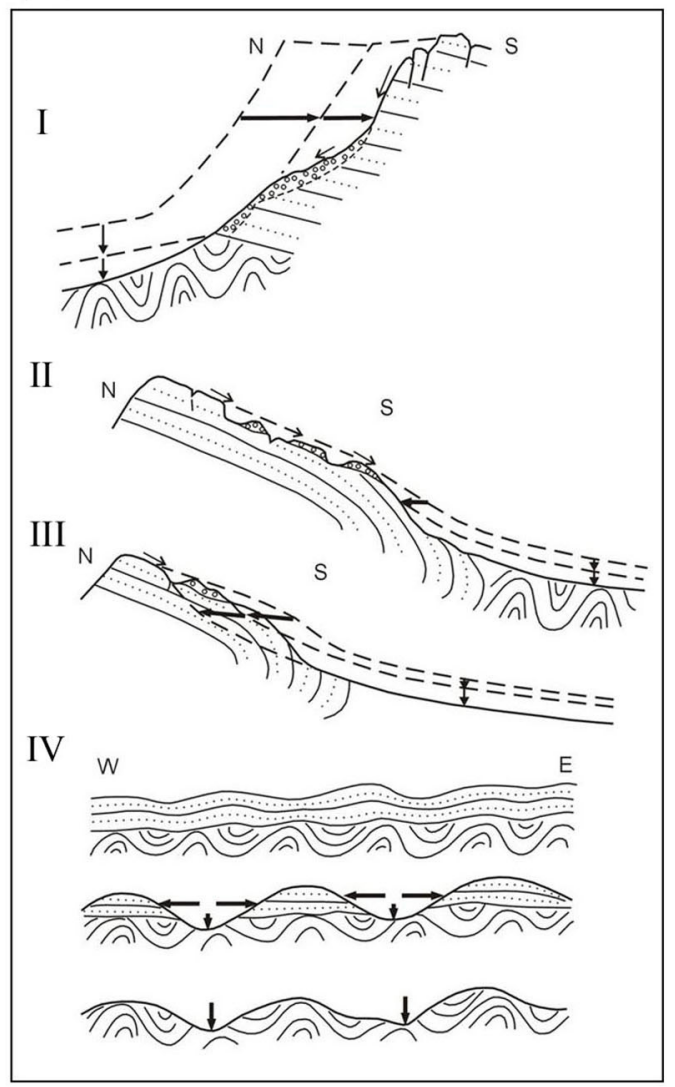

B
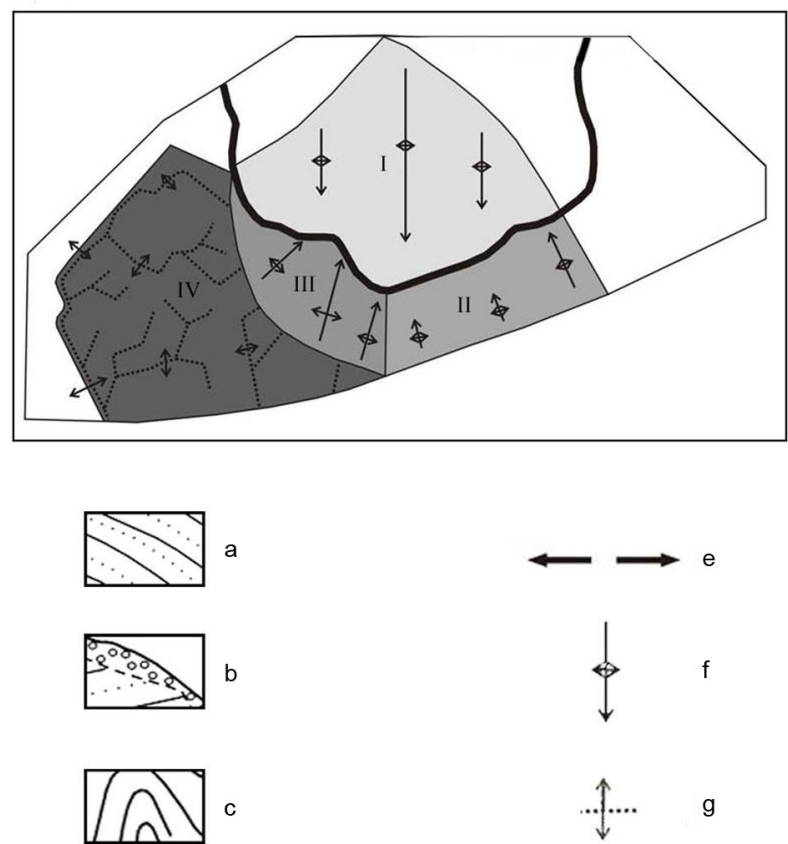

$\uparrow \ldots$

g

Fig. 10. Schematic relief evolution in selected sections of the Babia Góra massif. A - differences in slope retreat and valley deepening: I - northern slope and foreland (high rate of retreat of cuesta-type slope consisting of Magura sandstones, development of long and narrow valleys on sub-Magura layers), II - southern slope and foreland (slow retreat and lowering of dip slope and the development of short and shallow valleys on Magura sandstones), III - upper section of western slope (faster retreat of dip slopes than in II and larger and deeper valley development due to a lower erosion base; whole area consisting of the Magura sandstones), IV - lower section of western slope and foreland (a superimposed drainage network established in the Magura sandstones before their complete erosion in the form of a rectangular system of long and broad valleys), B - location of selected sections of the massif. a - Magura sandstones, b - colluvia, c - sub-Magura layers, $d$ - valley deepening, e - slope retreat, valley broadening, $\mathrm{f}$ - valley elongation and broadening in areas entirely or partly consisting of Magura sandstones, $\mathrm{g}$ - scale of valley broadening in areas with only the sub-Magura layers

on the northern foot slope led to formation of the massif main slope as a high cuesta. Short and shallow valleys on the southern side did not cause any significant change on the southern slope.

The Babia Góra massif relief evolution is driven by uplift, dissection of foot slopes and by slope retreat. N-S cross section in Figure 11 depicts the stages of this process in a schematical way. In an early stage all formations ontop Magura layers - and partly Magura layers itself -were eroded, initially in aquatic and subsequently in dry environment. The Upper Miocene planation surface created as a result of these processes. This should be regarded the starting point in any considerations of the massif relief evolution. It is estimated that on average at least two kilometres thick lay- er of rocks was eroded in this way in the Polish Carpathian Mountains (Baumgart-Kotarba 1974). It may be assumed that subsequent evolution of the area, including valley deepening and slope retreat, involved removal of a greater volume of rocks than lowering of the ridge top surface. During the Neogene, the massif uplift rate was generally on the wane, it peaked in its southern part where the thickness of the Magura sandstone in the syncline axis was greatest. As a result the main ridge axis shifted southwards. The deeper dissection of the northern slope caused it to retreat at a higher rate than the one across on the southern side. The northern slope of the massif took the form of high cuesta following a virtually complete erosion of Magura sandstones. This 


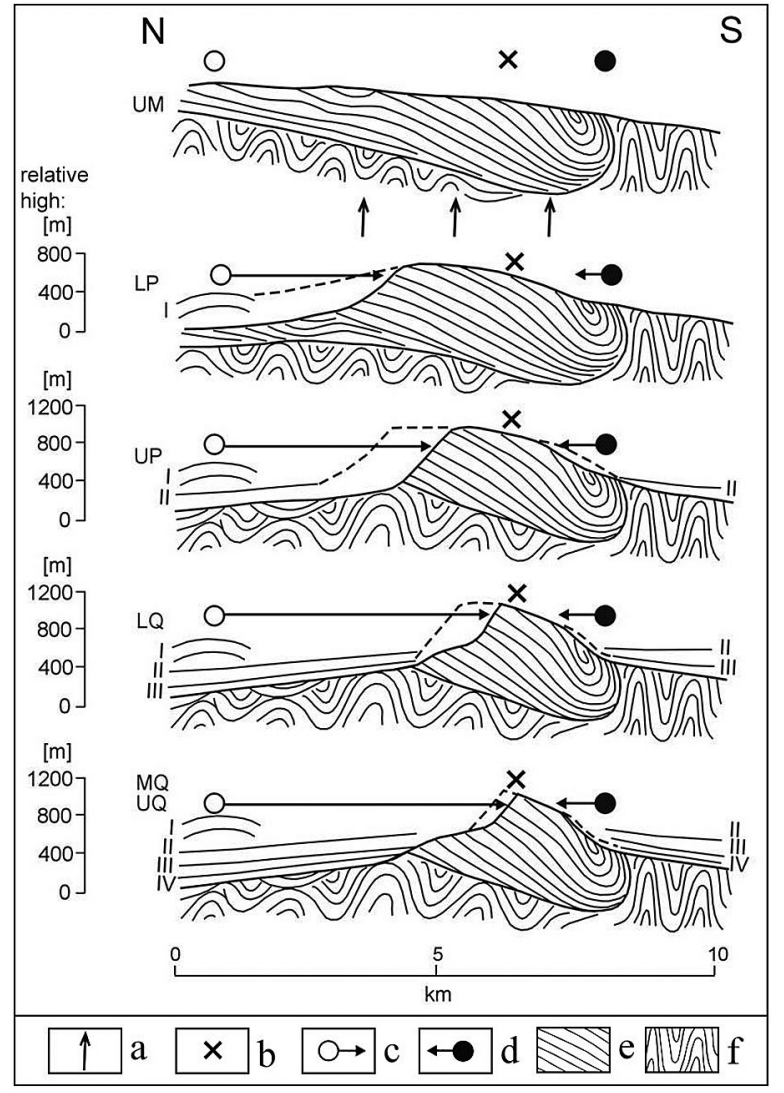

Fig. 11. Schematic diagram showing probable changes in the N-S cross-section of Babia Góra due to its uplift, dissection and slope retreat during the Neogene and Quaternary. UM - Upper Miocene, LP - Lower Pliocene, UP - Upper Pliocene, LQ - Lower Quaternary, MQ and UQ - Middle and Upper Quaternary. I-IV - planation surfaces (key as in Fig. 6B). a - area with the highest tectonic uplift, b-current highest point of the massif, $\mathrm{c}$ and $\mathrm{d}-$ key as for $\mathrm{f}$ and $\mathrm{g}$ on Fig. 6C, e - Magura sandstones, $\mathrm{f}-$ sub-Magura layers

was facilitated both by lower erosion base on the northern foreland and by concentric valley pattern in this section. The converging river pattern at the foot of the northern slope and greater river discharges on the wetter northern side should be regarded significant causes for more rapid valley deepening and, as a consequence, faster slope retreat. The zone of the greatest scale of relief change on the northern slope is five kilometres wide, while corresponding zone on the southern slope is just one kilometre wide. Figure 12 illustrates several debatable issues concerning the Babia Góra massif relief evolution in the Neogene and Quaternary periods.

Relief evolution of the Babia Góra massif takes place via slope retreat due to landsliding and valley deepening. Five general areas of different

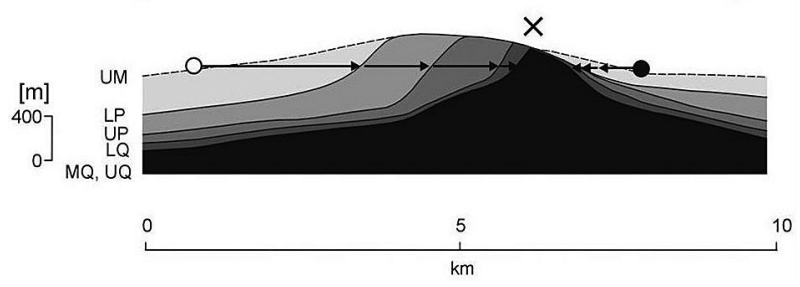

Fig. 12. Changes to the north-south cross section of the Babia Góra massif since the Upper Miocene. For explanations see Fig. 11. The figure illustrates relative altitudes in the area, i.e. the base of the massif in each figure should be referred to as $0 \mathrm{~m}$ altitude

age were identified across the massif (Fig. 13). The oldest area is the gentle uppermost part of the southern slope. Both the northern and western base of the massif are younger, with Magura sandstones eroded and valleys formed exclusively atop hieroglyphic layers. Slopes at lower altitudes, with headwater areas and landslides, mostly show even younger relief - formed solely in Magura sandstone. The upper part of the northern slope is younger and takes form of a large rock niche (Upper Pliocene/Lower Quaternary). The youngest landforms (Quaternary) associated with deep landslides can be found in a narrow zone of the highest part of the northern slope. Holocene relief evolution across the Babia Góra massif is negligible.

\section{Discussion and conclusions}

The results of this study are consistent with what is generally known about geomorphological evolution of the Polish Flysch Carpathians (see Starkel 1969, 1972, Baumgart-Kotarba 1974). This study contribution is finding of a much larger scale of changes to the Babia Góra massif relief during the Neogene and Quaternary periods (Łajczak 2012, 2013). A range of relic relief features dating to different periods was identified. Its evolution is closely related to tectonics and lithology of the massif. Such results however, must be treated with caution, in accordance with the approach advocated in recent years by Starkel $(1986,1992)$ and Zuchiewicz (2011).

The evolution of the Babia Gora massif relief is mainly driven by valley deepening, which causes landsliding what results inslopes retreat. Currently landslides cover nearly entire surface of 


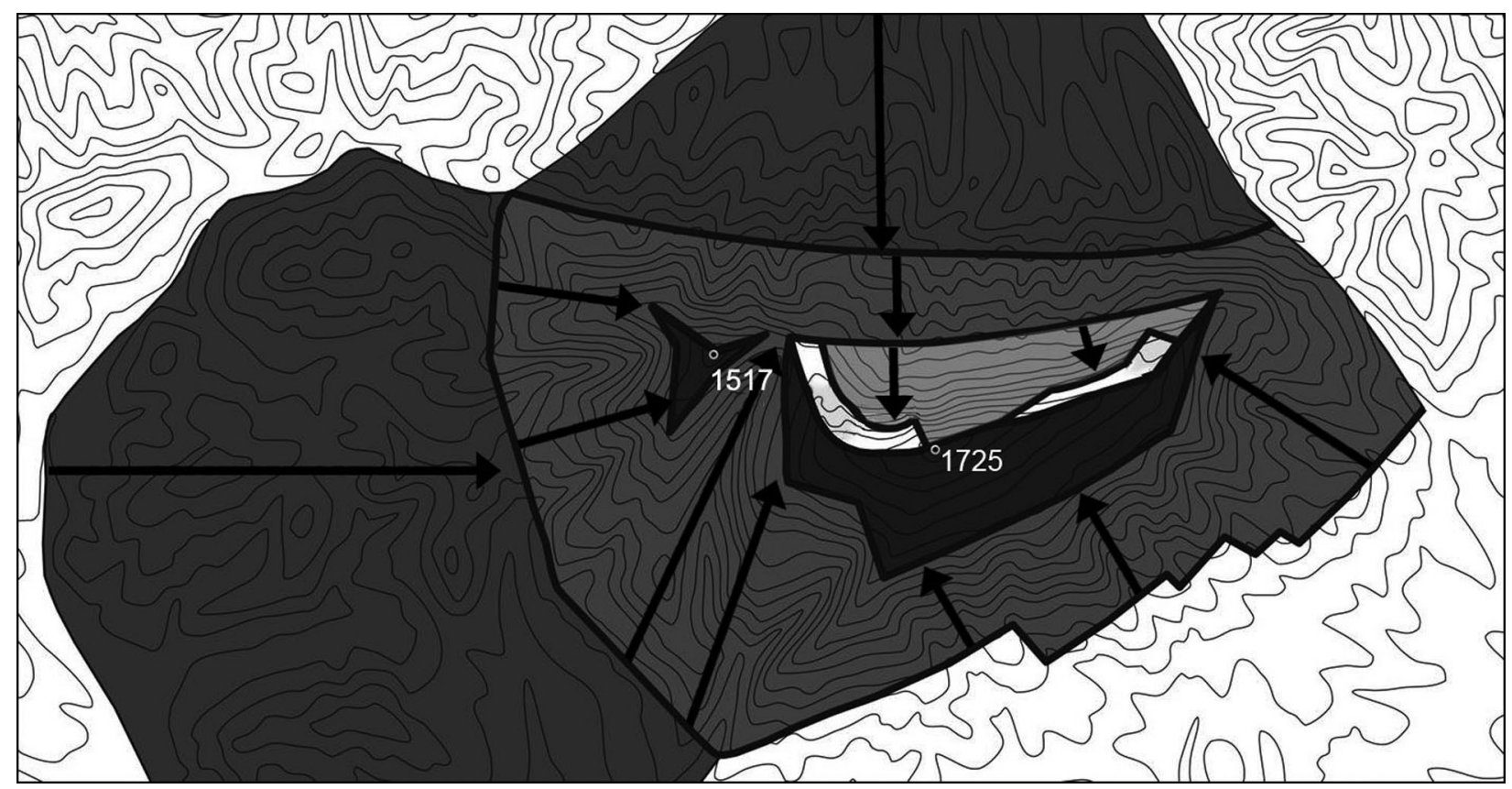

Fig. 13. Stages in the slope retreat and the relative age of landforms in selected parts of the Babia Góra massif (explanations in text). The areas with the oldest relief are marked in grey. Younger relief is marked using progressively lighter colours.

The arrows point to the direction of slope retreat

the massif slopes. The mechanisms of landslide development involved here and the landslide morphology produced are typical of those discussed in other studies (Hutchinson 1988, 1995, Cruden, Varnes 1996, Dikau et al. 1996, Margielewski et al. 2008). The landslides progressed uphill, which means that the youngest relief can be found in the highest locations, which is a common pattern in the flysch part of the Carpathian Mountains (Margielewski 2006, Margielewski et al. 2008, Alexandrowicz, Margielewski 2010). The highest gentle section of the southern slope, where landslides are less deep, compared to the northern slope, may be regarded representative of the oldest relief existing in the study area.

In his seminal work, which has influenced subsequent research on structural conditions in the evolution of the Babia Góra relief, Alexandrowicz (1978) was the first to propose an idea of staged evolution of the massif northern slope driven by deep landslides. He suggested that the youngest and highest-located landslide niches should be dated to the early Holocene period. The author of this study argued that proposition (Łajczak 1998) when discussing potential occurrence of glacially remodelled landslide niches at Babia Góra. Indeed, dating of the large niche on the northern slope to the early Holocene or even to the Atlantic Period (Ziętara 2004) must be considered unfounded. The analysis of the relief indicates that this landform, with a volume of ca. $1.5 \mathrm{~km}^{3}$, developed at the turn of the late Pliocene and early Quaternary periods. Younger age of the landform is ruled out by the lack of sufficiently thick layer of loose talus on the slope beneath and in the valley bottoms as well as the occurrence of solid-rock channels. The thickness of colluvia beneath that niche estimated to be 200 metres by Alexadrowicz (1978) and later repeated by Ziętara (2004) is overestimated at least 20 times. In this section of the northern slope the depth of the colluvial cover never exceeds single metres and even at the thickest points numerous slope trenches with rocky walls are visible.

A larger scale of valley deepening and a faster rate of slope retreat occurred in the northern part of the massif where a huge rock slump gives the slope a cuesta shape. Geomorphological formation of the southern side of the massif, where the slope is concordant to the dip of the sandstone layers, proceeds at the slowest rate. Also the western part of the massif experienced a large-scale landform transformation, evident in a large number of identified tectonic faults. The nature of relief visible on this slope appears intermediate between the types of relief on the southern and northern 
slopes. As a result, there is a strong asymmetry in the scale of geomorphological transformation of the massif along the N-S profile.

There is a number of features in geomorphological evolution that differentiate the Babia Góra massif from the rest of the flysch part of the Polish Carpathian Mountains. It can be explained based on the exceptional scale of uplift and dense pattern of tectonic fracturing in this area. The flysch section of the Carpathian Mountains is a typical example of a mountain range with polycyclic erosion-denudation type of relief, where the underlying structure has an impact on the relief but is not its main driving factor (Baumgart-Kotarba 1974). In the Babia Góra massif, on the other hand, the structural factor is clearly the primary driver of the landform development (Eajczak 2013). This conclusion is based on a sound recognition of the massif geology, which should always be the starting point in the analysis of the evolution of mountain relief (Baumgart-Kotarba 1974). The nature of Babia Góra's relief also seems to oppose to the general remark of Baumgart-Kotarba (1974) that in the flysch part of the Carpathian Mountains central inter-valley landforms are older than peripheral ridge sections. Indeed, in this towering massif the relief rejuvenation involves even some high slope sections, while the older relief of their bases remains unchanged. A similar point can be made with reference to Gerber's (1969) general statement about the fragmentation of various ridge types under the influence of headwater areas. In the Babia Góra massif both the asymmetrical fragmentation of the zigzagging ridgeline and the symmetrical fragmentation in the other sections is influenced by the underlying structure to the same degree. According to Baumgart-Kotarba (1974) the role of geological structure is smaller over shorter periods of dissection (fragmentation) of a mountain range than over longer periods, dominated by planation. Again, the Babia Góra massif seems to go against this pattern, since virtually all landforms analysed in this study are aligned with the joint lines of the geological structure. This would suggest that at the stage of their formation, i.e. the massif fragmentation during uplift, the underlying structure played no smaller part in the relief evolution than at the stage where planation dominated at the base. Baumgart-Kotarba (1974, p. 93) offers an explanation for the formation of high cuesta on Babia Góra's northern slope claiming that the retreat and slopes steepening leading to the formation of high cuestas begins only after the erosional elimination of more resistant rock layers, exposing less-resistant rocks.

Over time the rate of general transformation of the massif tended to decrease. It went from relatively high during the Neogene period, to much lower in the Quaternary, and to insignificant during the Holocene. As a result geomorphological contrasts between the northern and southern slopes of the massif tended to establish themselves rather than diminish.

\section{References}

Alexandrowicz S.W., 1978. The northern slope of Babia Góra Mt. as a huge rock slump. Studia Geomorphologica Carpatho-Balcanica 12: 133-148.

Alexandrowicz S.W., 2004. Outlines of geology of the Babia Góra range. In: B.W. Wołoszyn, A. Jaworski, J. Szwagrzyk (eds), The Nature of the Babiogórski National Park Kraków: 87-107.

Alexandrowicz Z., Margielewski W., 2010. Impact of mass movements on geo- and biodiversity in the Polish Outer (Flysch) Carpathians. Geomorphology 123: 290-304.

Baumgart-Kotarba M., 1974. Development of mountain ridges in the flysch Carpathians. Geographical Studies 106: 1-136.

Bober L., 1984. Landslide areas in the Polish Flysch Carpathians and their connection with the geological structure of the region. Biuletyn Instytutu Geologicznego 340: 115-158.

Brunsden D., 1993. Mass movements; the research frontier and beyond: a geomorphological approach. Geomorpho$\log y$ 7: 85-128.

Cendrero A., Dramis F., 1996. The contribution of landslides to landscape evolution in Europe. Geomorphology 15: 191-211.

Cruden D.M., Varnes D.J., 1996. Landslide types and processes. In: A.K. Turner, R.L. Schuster (eds), Landslides: investigation and mitigation. Transportation Research Board, Washington D.C., Special Report 247: 36-75.

Demek J., Mackovčin P., Slavik P., 2011. Geomorphological conditions of the Mine Area Trojanovice in the Moravian-Silesian Carpathians, Czech Republic. Studia Geomorphologica Carpatho-Balcanica 45: 5-24.

Dikau R., Brunsden D., Schrott L., Ibsen M.L. (eds), 1996. Landslide recognition. Identification, movement and causes. Wiley, Chichester pp. 251.

Geological Atlas of the Western Outer Carpathians and Their Foreland, 1:500 000, 1988-1989. Państwowy Instytut Geologiczny Warszawa.

Gerber E., 1969. Bildung und Formen von Gratgipfeln und Felswänden in den Alpen. Zeitschrift für Geomorphologie Suppl. 8: 94-118.

Hutchinson J.N., 1988. Morphological and geotechnical parameters of landslides in relation to geology and hydro- 
geology. In: C. Bonnard (ed.), Proc. of $5^{\text {th }}$ Intern. Symp. on Landslides 1. Balkena, Rotterdam: 3-35.

Hutchinson J.N., 1995. Deep-seated mass movements on slopes. Mem. Soc. Geol. Itn. 50: 147-164.

Kasprzak M., 2013. The Stołowe Mountains - studies in geomorphometry and new facts about landforms. In: P. Migoń, M. Kasprzak (eds), Sandstone landscapes. Diversity, ecology and conservation. Proc. of Wrocław University: 77-84.

Książkiewicz M., 1983. The geology of the Babia Góra region. In: K. Zabierowski (ed.), National Park on the Babia Góra Mt. Nature and Man. Studia Naturae B 29: 25-39.

Łajczak A., 1998. Distribution of glacial and nival forms in the Babia Góra massif, Western Carpathians. Proc. of the $4^{\text {th }}$ Meeting of Polish Geomorphologists Part II, Lublin: 349-356.

Łajczak A., 2004. Waters of Mount Babia Góra. In: B.W. Wołoszyn, A. Jaworski, J. Szwagrzyk (eds), The Nature of the Babiogórski National Park Kraków: 153-177.

Łajczak A., 2012. Water circulation and chemical denudation within the upper Skawica River flysch catchment, Western Carpathian Mountains. Zeitschrift für Geomorphologie 56: 69-86.

Łajczak A., 2013. Relief development of a highly elevated monoclinal Babia Góra range built by Magura sandstone, Western Carpathian Mts. In: P. Migoń, M. Kasprzak (eds), Sandstone landscapes. Diversity, ecology and conservation. Proc. of Wrocław University: 100-105.

Margielewski W., 2006. Structural control and types of movements of rock mass in anisotropic rocks: case studies in the Polish Flysch Carpathians. Geomorphology 77: 47-68.

Margielewski W., Święchowicz J., Starkel L., Łajczak A., Pietrzak M., 2008. Present-day evolution of the relief of the Flysch Carpathians. In: L. Starkel, A. Kostrzewski, A. Kotarba, K. Krzemień (eds.), Present-day changes in relief in Poland's territory, Kraków: 57-133.

Migoń P., 2008. Relief and geomorphological development. In: A. Witkowski, B.M. Poryszko, W. Ciękowski (eds), The Nature of Góry Stotowe National Park: 49-69.
Pánek T., Hradecký J., Smolková V., Šilhan K., Minár J., Zernitskaya V., 2010. The largest prehistoric landslide in northwestern Slovakia: Chronological constraints of the Kykula long-runout landslide and related dammed lakes. Geomorphology 120: 233-247.

Rehman A., 1895. Physico-geographical description of the territory of Poland and neighbouring Slavonic countries. Part - Physico-geographical description of the Carpathians. Lwów-Kraków, pp. 250.

Starkel L., 1969. The age of the stages of development of the relief of the Polish Carpathians in the light of the most recent geological investigations. Studia Geomorphologica Carpatho-Balcanica 3: 33-44.

Starkel L., 1972. Outer Carpathians. In: Klimaszewski M. (ed.), Geomorphology of Poland Warszawa: 52-115.

Starkel L., 1986. The role of the inherited forms in the present-day relief of the Polish Carpathians. In: V. Gardiner (ed.), International Geomorphology, Part II, Wiley, London: 1033-1045.

Starkel L., 1992. The diversity of the relief of mountains and uplands, their palaeogeomorphological reconstruction and prognosis. Przeglad Geograficzny 64(1-2): 87-94.

Starkel L., Łajczak A., 2008. Formation of relief of valley bottoms, channels and floodplains in the Carpathians. In: L. Starkel, A. Kostrzewski, A. Kotarba, K. Krzemień (eds), The present-day changes in relief of Poland's territory. Proc. of Jagiellonian University, Kraków: 95-114.

Ziętara T., 1988. Landslide areas in the Polish Flysch Carpathians. Folia Geographica, ser. Geographica-Physica 20: 21-31.

Ziętara T., 2003. Transformation of cryoplanation terraces during the Holocene in the Flysch Carpathians. Geomorphologia Slovaca 3(1): 80-82.

Ziętara T., 2004. Relief of Mount Babia Góra. In: B.W. Wołoszyn, A. Jaworski, J. Szwagrzyk (eds), The Nature of the Babiogórski National Park, Kraków: 109-135.

Zuchiewicz W., 2011. Planation surfaces in the Polish Carpathians: myth or reality? Geographia Polonica 84 , Special Issue Part 2: 155-178. 